\title{
miR-21-5p regulates type II alveolar epithelial cell apoptosis in hyperoxic acute lung injury
}

\author{
SONG QIN, MIAO CHEN, HUI JI, GUO-YUE LIU, HONG MEI, KANG LI and TAO CHEN \\ Intensive Care Unit, Affiliated Hospital of Zunyi Medical College, Zunyi, Guizhou 563000, P.R. China
}

Received November 2, 2016; Accepted June 22, 2017

DOI: $10.3892 / \mathrm{mmr} .2018 .8560$

\begin{abstract}
Hyperoxia-induced acute lung injury (HALI) as one of the most common complications in patents on mechanical ventilation, and there are no efficient methods to overcome this at present. It was hypothesized that microRNA 21-5p(miR-21-5p) can promote the survival of type II alveolar epithelial cells (AECII), alleviating HALI. The present study aimed to combine gene chip analysis with the overexpression miR-21-5p to develop a novel therapeutic option for HALI. It was found that AECII apoptosis was an important pathogenic event in the development of HALI, and the overexpression of miR-21-5p prevented HALI, associated with reducing AECII apoptosis. These results were obtained using adenoviral/lentiviral vectors, which overexpressed miR-21-5p, to transfect AECII cells in vitro and in vivo. It was found that the overexpression of miR-21-5p reduced the apoptotic rate of the AECII cells. In addition, miR-21-5p decreased the ratio of B-cell lymphoma 2 (Bcl-2)-associated X protein/Bcl-2 and the expression of caspase-3. It was also revealed that the overexpression of miR-21-5p alleviated acute lung injury in adult rats exposed to a hyperoxic environment. These results suggest that miR-21-5p may become a novel therapeutic option for patients with HALI, by protecting AECII cells from apoptosis.
\end{abstract}

\section{Introduction}

A large number of critically ill patients with refractory hypoxemia require high oxygen treatment in the clinical treatment process, however, long exposure to a high level of oxygen can lead to hyperoxia-induced acute lung injury (HALI), and can result in bronchial pulmonary hypoplasia in newborns and adult acute respiratory distress syndrome (ARDS) (1). How to treat refractory hypoxemia and avoid or mitigate HALI is a problem, for which a solution is urgently required in

Correspondence to: Dr Miao Chen, Intensive Care Unit, Affiliated Hospital of Zunyi Medical College, 149 Dalian Road, Zunyi, Guizhou 563000, P.R. China

E-mail: chenmiao_2106@163.com

Key words: type II alveolar epithelial cell, apoptosis, microRNA, gene chip, high oxygen acute lung injury clinical practice. HALI (2), ARDS (3), chronic obstructive pulmonary diseases (4), pulmonary fibrosis (5) and other lung diseases caused by oxidative stress, are the primary reasons for type II alveolar epithelial cell (AEC-II) apoptosis. AEC-II are the primary targeting cells for high oxygen $(2,6)$, AEC-II apoptosis is considered to be the underlying pathogenesis of HALI (7-9), and the inhibition of AEC-II can effectively reduce the degree of HALI apoptosis $(10,11)$. The survival or apoptosis of AEC-II directly affect the degree of lung injury and repair (12). Oxidative stress caused by cell apoptosis is mediated primarily by reactive oxygen species (ROS). The release of superoxide anion $\mathrm{O}^{-}$and hydrogen peroxide $\left(\mathrm{H}_{2} \mathrm{O}_{2}\right)$ into the alveolar space, involved in the pathophysiological changes of these diseases, triggers AEC-II apoptosis (13). $\mathrm{H}_{2} \mathrm{O}_{2}$ is considered the most suitable ROS as a signaling molecule, and is widely used to induce cell oxidative damage and apoptosis in models (14). In previous years, studies have found that microRNAs (miRNAs) are key in a variety of cell apoptosis signal transduction pathways (15-18). Therefore, from the perspective of the regulation of AEC-II apoptosis, miRNA may have potential clinical value in the prevention and treatment of HALI. The present study used gene chip technology to screen AEC-II apoptosis-related miRNAs, and examined their possible mechanisms. This may identify novel strategies for the clinical prevention and treatment of HALI in the future.

\section{Materials and methods}

Materials. In the first experiment, rat AEC-II cells were provided by the Central Laboratory of Xiangya Medical School (Changsha, China). Cells were recovered and subcultured, and when cultured in RPMI-1640 medium (Thermo Fisher Scientific, Inc., Waltham, MA, USA) at $37^{\circ} \mathrm{C}$ for $36 \mathrm{~h}$, the culture was divided into two groups. In the $\mathrm{H}_{2} \mathrm{O}_{2}$ damage groups, $0.5 / 1 \mathrm{H}_{2} \mathrm{O}_{2}$ was added and culture was continued; in the blank control group, the same volume of saline was added and culture was continued.

In the second experiment, a total of 160 Sprague-Dawley (SD) rats ( 180-220 g; male and female informality) were provided by the Animal Experiment Center of the Third Military Medical University [Chongqing, China; animal license no: SCXK (Chongqing) 2012-0005]. The rats were maintained at $18-22^{\circ} \mathrm{C}$, a relative humidity of $50-60 \%$ and a $12 \mathrm{~h}$ light/dark cycle with free access to rat chow and water. 
Rats were randomly divided into four groups: i) normal control group $(2.5 \%$ pentobarbital sodium via abdominal cavity anesthesia); ii) PBS group (2.5\% pentobarbital sodium via abdominal cavity anesthesia and administration of $200 \mu \mathrm{l}$ PBS through nose drop); iii) Empty virus group, (2.5\% pentobarbital sodium via abdominal cavity anesthesia and administration of $200 \mu$ slow virus through nose drop); iv) miRNA-21-5p group $(2.5 \%$ pentobarbital sodium via abdominal cavity anesthesia and administration of $200 \mu$ slow virus containing miRNA-21-5p through nose drop). The high oxygen acute lung injury model was established in all four groups (each $n=40$ ), in accordance with a previous study (19). Any rats which died in the modeling process were excluded from the experiment.

In the third experiment, the subcultured AEC-II cells were randomly divided into four groups: Normal control group (saline), $\mathrm{H}_{2} \mathrm{O}_{2}$ damage group $\left(0.5 \mathrm{mmol} / 1 \mathrm{H}_{2} \mathrm{O}_{2}\right)$, miR-21-5p overexpression group (adenovirus vector with miR-21-5p+0.5 mmol/1 $\mathrm{H}_{2} \mathrm{O}_{2}$ ), miR-21-5p negative transfection group (empty adenovirus $+0.5 \mathrm{mmol} / 1 \mathrm{H}_{2} \mathrm{O}_{2}$ ). Indicators were measured at $6,12,24$ and $48 \mathrm{~h}$, respectively.

AEC-II detection. The use of transmission electron microscopy (TEM) for detection of lamellar corpuscle osmium is considered the gold standard for the identification of AEC-II. The specimens were identified using electron microscopy at the Zunyi Medical College Electron Microscopy Center (Zunyi, China).

Morphological detection of apoptosis. The $\mathrm{H}_{2} \mathrm{O}_{2}$ model cells were collected $24 \mathrm{~h}$ following incubation with $0.5 \mathrm{mmol} / 1$ $\mathrm{H}_{2} \mathrm{O}_{2}$ for $24 \mathrm{~h}$. Subsequently, TEM was used to detect apoptotic morphology, using the same method as described above for AEC-II identification.

Detection of early apoptotic rate. In each group, the cells were collected at five time points: Prior to modeling (T0) and 2.5, 6, 12 and $24 \mathrm{~h}$ following modeling (T2.5, T6, T12 and T24, respectively) for the preparation of single cell suspensions. The cells were centrifuged at $4^{\circ} \mathrm{C}$ and $125 \mathrm{x} \mathrm{g}$ for $5 \mathrm{~min}$, the supernatant was discarded, and the cells were washed once with PBS.

Gene chip screening and bioinformatic analysis of apoptosis-related miRNAs. The cells were collected from the T0 and T2 4 cell groups to perform the miRNA microarray to compare the differential expression profile of miRNAs between the two time points, and for screening apoptosis-related miRNAs. RNA quantity was measured using a NanoDrop 1000 (Thermo Fisher Scientific, Inc.) and the samples were labeled using the miRCURY LNA ${ }^{\mathrm{TM}}$ microRNA Array Hi-Power Labeling kit (Qiagen, Inc., Germantown, MD, USA), followed by hybridization onto a miRCURY LNA ${ }^{\mathrm{TM}}$ miRNA array (version 18.0; Qiagen, Inc.). The slides were washed prior to scanning with an Axon GenePix 4000 B microarray scanner (Molecular Devices, LLC., Sunnyvale, CA, USA). Scanned images were then imported into the GenePix Pro 6.0 program (Molecular Devices, LLC.) for grid alignment and data extraction. Replicated miRNAs were averaged, and miRNAs with intensities of $>50$ in all samples were used to calculate a normalization factor. Expressed data were normalized by median normalization. Following this, the miRNAs that were significantly differentially expressed were identified by a volcano plot. Finally, hierarchical clustering was performed to determine the differences in the miRNA expression profiles among the samples using WebMeV software (version 4.6; http://mev.tm4.org/) (20).

To further investigate the functional roles of miRNA, the putative targets of miR-449a-5p, miR-34b/c-5p and miR-21-5p were predicted by TargetScan (http://www.targetscan.org/), miRecords (http://c1.accurascience.com/miRecords/) and miRTarBase (http://mirtarbase.mbc.nctu.edu.tw/php/index. php) databases.

Reverse transcription-polymerase chain reaction (RT-PCR) validation of apoptosis-related miRNAs. The miR-21-5p, miR-34c-5p, miR-449a-5p and U6 primers were designed by Boheng Biomart (Beijing, China). Total RNA from AEC-II cells was isolated using the RNAiso Kit (Takara Biotechnology Co., Ltd., Dalian, China). RNA concentration and purity was checked using a Varioskan Flash spectrophotometer (Thermo Fisher Scientific, Inc.). A total of 500 ng RNA was reverse transcribed to cDNA using the PrimeScipt RT Reagent Kit (Takara Biotechnology Co., Ltd.) in a final volume of $10 \mu \mathrm{l}$, according to the manufacturer's protocol. RT-PCR was performed with a CFX Connect Real-Time system (Bio-Rad Laboratories, Inc., Hercules, CA, USA) using a SYBR green PrimeScript RT kit (Takara Biotechnology Co., Ltd.). and the following thermocycling conditions: Initial denaturation at $95^{\circ} \mathrm{C}$ for $5 \mathrm{~min}$, followed by 40 cycles of denaturation at $95^{\circ} \mathrm{C}$ for $10 \mathrm{sec}$ and combined annealing/extension at $65.7^{\circ} \mathrm{C}$ for $30 \mathrm{sec}$. The primer sequences were as follows: miR-34c-5p forward, 5'-CCAGGC AGTGTAGTTAGCT-3' and reverse, 5'-GTTGGCTCTGGT GCAGGGTCCGAGGTATTCGCACCAGAGCCAACGCAA TC-3'; miR-449a-5p forward, 5'-AACGTGGCAGTGTATTGT TA-3' and reverse, 5'-GTTGGCTCTGGTGCAGGGTCCGAG GTATTCGCACCAGAGCCAACACCAGC-3'; U6 forward, 5'-CTCGCTTCGGCAGCACACG-3' and reverse, 5'-AAC GCTTCACGAATTTGCGT-3'. U6 was used as an internal control. The relative expression levels were calculated using the $2^{-\Delta \Delta \mathrm{Cq}}$ method (21).

Establishment of the hyperoxia lung injury model. The high oxygen tank comprised a plexiglass container $(45 \times 30 \times 35 \mathrm{~cm})$ with a top pick oxygen connector and oxygen detector. The SD rats were placed in the high oxygen tank, the inside temperature was maintained at $25-27^{\circ} \mathrm{C}$ and a humidity of $50-70 \%$, the oxygen flow rate was adjusted so that the oxygen concentration inside was sustained at $\geq 90 \%$. Soda lime inside the tank was used to absorb $\mathrm{CO}_{2}$ to maintain the $\mathrm{CO}_{2}$ concentration $<0.5 \%$. Continuous oxygen was supplied for $23.5 \mathrm{~h}$, with the box opened for $30 \mathrm{~min}$ every day for feeding of food and water, and litter removed at dawn.

miRNA-21-5p transfection. The SD rats were anesthetized intraperitoneally and placed supine on the experimental console. A $10 \mu 1$ drop of miRNA-21-5p lentivirus fluid was administered through one naris, followed by a $10 \mu \mathrm{l}$ drop of miRNA-21-5p lentivirus fluid into the other naris. This operation was performed 2 min after anesthesia was established. The procedure was repeated 20 times in $2 \mathrm{~min}$, with a total of 
$200 \mu \mathrm{l}$. At 0, 24, 48 and $72 \mathrm{~h}$ following the drop administration, the rats were sacrificed. A section of lung tissue was removed, embedded, fixed and cut into sections $\left(0.3 \times 0.3 \times 0.5 \mathrm{~cm}^{3}\right)$, following which fluorescence microscopy was used to observe the distribution of green fluorescence. The same method was used to administer drops of the same doses of PBS and lentivirus, which were used as a control group.

The optimal transfection titer comprised six titers of the $200 \mu 1$ lentiviral solution $\left(1 \times 10^{6}, 2 \times 10^{6}, 4 \times 10^{6}, 6 \times 10^{6}, 8 \times 10^{6}\right.$ and $10 \times 10^{6} \mathrm{TU} / \mathrm{ml}$ ) by nasal instillation into rat lungs. Lung tissue changes were observed in general and using fluorescence microscopy to observe changes in lung tissue fluorescence. The concentration at which no increase in fluorescence density was observed was considered the optimal transfection titer, in addition to the increased transfection titer.

Detection of respiratory parameters. In the model rats at 0 , 24, 48 and $72 \mathrm{~h}$, arterial blood was extracted for gas analysis, and the oxygenation index (OI) and respiratory index (RI) were calculated according to the following formula based on blood gas analysis results: $\mathrm{OI}=\mathrm{PaO}_{2} / \mathrm{FiO}_{2} . \mathrm{PaO}_{2}$ is the arterial oxygen pressure, $\mathrm{FiO}_{2}$ is the fraction of inspired $\mathrm{O}_{2}$ or the inspired oxygen concentration. The $\mathrm{FiO}_{2}$ was recorded as $90 \%$. $\mathrm{RI}=\mathrm{P}(\mathrm{A}-\mathrm{a}) \mathrm{O}_{2} / \mathrm{PaO}_{2}$. $\mathrm{P}(\mathrm{A}-\mathrm{a}) \mathrm{O}_{2}$ is the alveolar-arterial oxygen tension gradient (alveolar-arterial oxygen difference).

Light microscopic examination of lung tissue and pathological scoring. Tissue specimens were obtained from the high oxygen model $0,24,48$ and $72 \mathrm{~h}$ rats, respectively, following sacrifice. A $0.3 \times 0.3 \times 0.5 \mathrm{~cm}^{3}$ sample of right lung tissue was fixed in $10 \%$ formalin fluid, dehydrated, embedded in paraffin and cut into $5-8-\mu \mathrm{m}$ sections, with dimethyl benzene dewaxing following hematoxylin and eosin staining. The sections were dehydrated again, cleared in xylene and rubber sealed, following which the pathological changes of lung tissues were observed with a Leica DM4M microscope (Leica Microsystems GmbH, Wetzlar, Germany). Each tissue biopsy was scored in three randomly selected high-power fields (magnification, $\mathrm{x} 400$ ), and the average value was calculated using a scoring system $(22,23)$, according to the structural damage and inflammatory cell infiltration of lung tissue.

Determination of lung tissue wet/dry (W/D) weight ratio. The rats were raised in high oxygen for $0,24,48$ and $72 \mathrm{~h}$, respectively, and sacrificed. The left lung was removed and weighed to determine the lung wet weight. The lung tissue was then placed in a constant temperature oven at $80^{\circ} \mathrm{C}$ for $48 \mathrm{~h}$ until the weight was constant, and recorded as the dry weight of the lung. The W/D ratio was calculated based on the above data.

AEC-II transfection. Logarithmic growth phase cells were seeded into six-well plates $\left(5 \times 10^{7}\right.$ cells $\left./ \mathrm{cm}^{2}\right)$ until the cells covered the bottom of the well, following which $0.125 \%$ trypsin/EDTA was used for digestion of cells and counted. Adenovirus liquid $(10 \mu \mathrm{l})$ was added to $10 \mathrm{ml}$ serum-free 1640 medium dilution, the optimal multiplicity of infection (MOI) was determined. Following successful transfection with Lipofectamine $^{\circledR} 2000$ (Invitrogen; Thermo Fisher Scientific, Inc.), the highest transfection efficiency time point was determined according to the green fluorescence emitted.
RT-PCR analysis of miR-21-5p. The miR-21-5p primers were designed by Beijing Booheng Kechuang Biological Technology Co., Ltd. (Beijing, China) for reverse transcription of AEC-II with the highest transfection efficiency time in each group. RT-PCR analysis was performed as described above to detect the expression of miR-21-5p in each group, with U6 as the internal control.

Detection of early apoptotic cells with flow cytometry (FCM). The optimal MOI was 30. The overexpression and negative miR-21-5p adenovirus vectors were transfected into the AEC-II and, following successful transfection, the cells were subjected to $0.5 \mathrm{mmol} / \mathrm{l} \mathrm{H}_{2} \mathrm{O}_{2}$ injury for $6,12,24$ and $48 \mathrm{~h}$. For each time point, each cell suspension was prepared by centrifugation for $5 \mathrm{~min}$ at $4^{\circ} \mathrm{C}$ and $125 \mathrm{x} \mathrm{g}$, removal of supernatant and washing once in PBS. According to process of the double marking FCM, the early apoptotic rates of the cells were determined.

Western blot analysis of the expression of $\mathrm{Bcl}-2, \mathrm{Bax}$ and Caspase-3. AEC-II cells at $48 \mathrm{~h}$ post-transfection were placed in EP tubes, washed twice with PBS, added to the cell lysate, subjected to ultrasound disruption and centrifuged. Extraction of whole protein was performed by boiling at $100^{\circ} \mathrm{C}$ for $5 \mathrm{~min}$. Protein concentration was determined with the bicinchoninic acid protein assay. The proteins (50 $\mu \mathrm{g} /$ lane) were and separated by $10 \%$ SDS-PAGE and transferred to polyvinylidene fluoride (PVDF) membranes. Following blocking in 5\% non-fat milk solution at room temperature for $2 \mathrm{~h}$, membranes were probed with anti-Bcl-2 (1:1,000; cat no. ab117115; Abcam, Cambridge, MA, USA), anti-Bax (1:1,000, cat no. ab77566; Abcam), anti-caspase-3 $(1: 1,200$; cat no. ab13585; Abcam) and anti- $\beta$-actin (1:500; cat no. ab8226; Abcam) primary antibodies at $4^{\circ} \mathrm{C}$ overnight. PVDF membranes were subsequently incubated with horseradish peroxidase-conjugated secondary antibodies (1:2,000; cat no. ab6728; Abcam) at room temperature for $1 \mathrm{~h}$. An enhanced chemiluminescence substrate (GE Healthcare, Chicago, IL, USA) was used to visualize the bands, which were analyzed by a ChemiDoc MP system (Bio-Rad Laboratories, Inc.). Protein levels were normalized to $\beta$-actin.

Statistical analysis. SPSS 19.0 statistical software (IBM SPSS, Armonk, NY, USA) was used for data analysis. Data were analyzed using one-way analysis of variance followed by the Least Significant Difference post-hoc test for multiple comparisons. All data are expressed as the mean \pm standard deviation. $\mathrm{P}<0.05$ was considered to indicate a statistically significant difference.

\section{Results}

AEC-II Identification. The TEM showed the characteristic structure of AEC-II, including osmiophilic lamellar bodies and microvilli (Fig. 1).

Apoptotic morphology detection. The TEM showed cytoplasmic retraction, chromatin condensation, margination, disappearance of cell surface microvilli, and emptying of osmiophilic lamellar bodies (Fig. 2). 


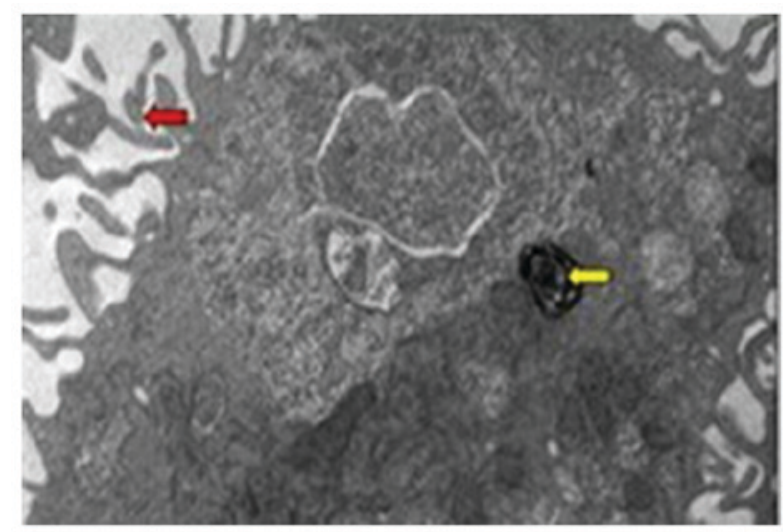

Figure 1. Transmission electron microscopy of normal AEC-II (magnification, $\mathrm{x} 8,000$ ). The yellow arrow indicates osmiophilic lamellar body and the red arrow indicates microvilli.

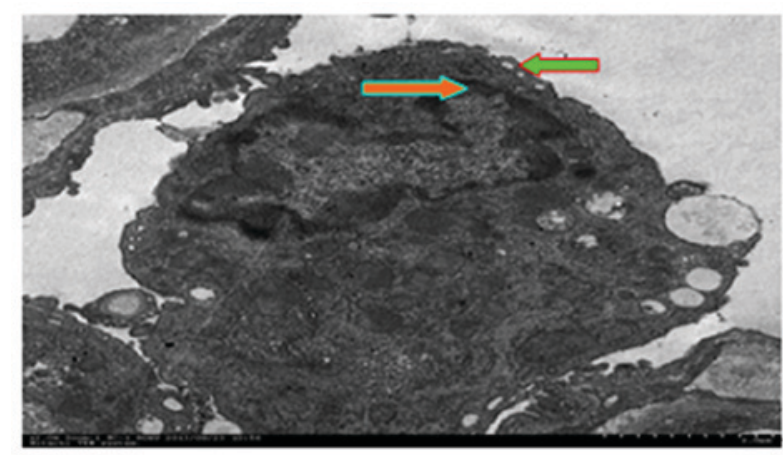

Figure 2. Apoptotic morphology detected using a transmission electron microscope (magnification, $x 8,000$ ). The red arrow indicates chromatin margination and the green arrow indicates condensation. The results show microvilli disappearance.

Detection of early apoptotic rates. Exposure to $\mathrm{H}_{2} \mathrm{O}_{2}$ induced a significant increase in apoptotic rate of the model cells, and this gradually increased with prolonged modeling (Fig. 3; Table I).

Gene chip to screen apoptosis-related miRNAs. On comparing the T0 cells and T24 cells, differentially expressed miRNAs were identified, among which rno-miR-449a-5p, rno-miR-34b/c-5p, rno-miR-21-5p and 13 miRNAs are closely associated with apoptosis (Fig. 4).

RT-PCR validation of apoptosis-related miRNAs. The expression levels of rno-miR-449a-5p, rno-miR-34-5p and rno-miR-21-5p were significantly lower, which was consistent with the gene chip results and indicated that the gene chip results were accurate and reliable (Fig. 4).

\section{Respiratory parameters in the four groups of rats}

OI change. As the injury time extended, the OI gradually reduced. No statistically significant difference was found in OI between the hyperoxia $0 \mathrm{~h}$, and control groups $(\mathrm{P}>0.05)$. Compared with the control group and empty virus group, no differences were observed in the groups exposed to hyperoxia for 24,48 and $72 \mathrm{~h}(\mathrm{P}<0.05)$. The expression of, OI was significantly higher in the miRNA-21-5p group $(\mathrm{P}<0.05$; Table II).

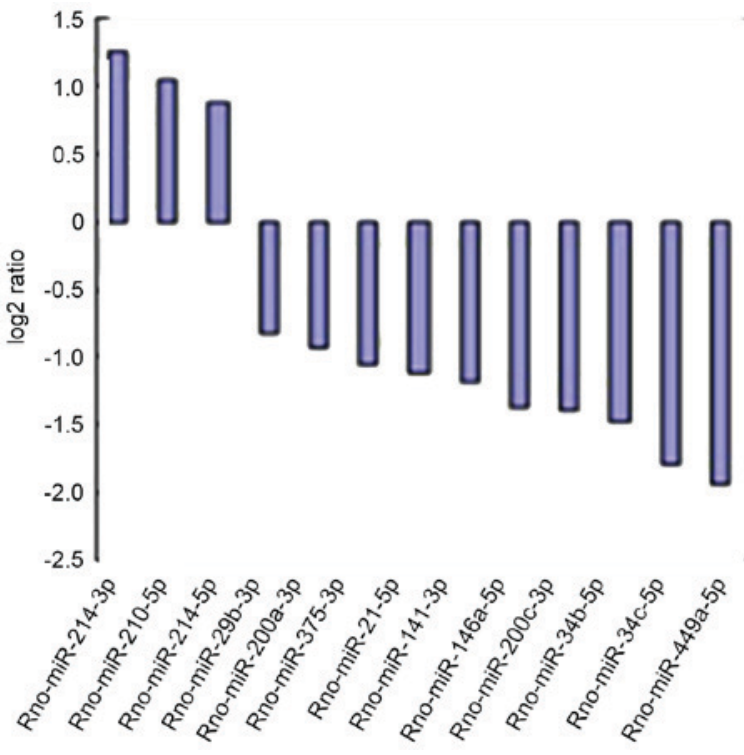

Figure 3. Apoptosis related miRNAs (T24 vs. T0). The ordinate shows the $\log 2$ (ratio). A $\log 2$ (ratio) $>0.8$ or $<-0.8$ difference was considered statistically significant. miR, microRNA.

RI change. As the injury time extended, the RI gradually increased. No significantly statistical difference was found between the hyperoxia $0 \mathrm{~h}$ and control groups. No significant differences were observed in RI in the hyperoxia 24,48 and $72 \mathrm{~h}$ groups, compared with the control group, PBS group and empty virus group $(\mathrm{P}>0.05)$. The expression of RI in the miRNA-21-5p group was significantly lower $(\mathrm{P}<0.05$; Table III).

\section{Lung tissue pathological changes and scores in the four groups of rats}

Light microscope pathological changes in lung tissue. In the rats exposed to hyperoxia for $0 \mathrm{~h}$, lung alveolar structures were clear, the alveolar septum was without exudation edema; no broadening of the alveolar interval was observed and there was no obvious exudation in the alveolar space. In the rats exposed to hyperoxia for $24 \mathrm{~h}$, each alveolar interval showed marginal edema, widening, and a low level of inflammatory cell infiltration. In the rats exposed to hyperoxia for $48 \mathrm{~h}$, the control group, PBS group and empty virus group exhibited lung tissue structure disorder, alveolar wall fracture damage, merging into pulmonary bullae, alveolar interval edema, broadening, a high level of inflammatory cell infiltration, alveolar cavities in the edema fluid, inflammatory cells and small red blood cells; however, the damage in the miRNA21-5p group was significantly reduces, compared with that in the other three groups. In the hyperoxia $72 \mathrm{~h}$ group, the control group, PBS group and the empty virus group structures were significantly disordered in lung tissues, marked alveolar wall fracture and alveolar cavity collapse were observed, alveolar capillary expansion was present, and, a high level of inflammatory cell infiltration was present. In the alveolar interval and alveolar space, red blood cells were visible, however the damage in the miRNA21-5p group was significantly reduced, compared with the other three groups (Fig. 5).

Comparing lung tissue biopsy scores. With prolonged injury, the lung pathology scores were gradually increased. Under 
Table I. Apoptotic ratios following various durations of $0.5 \mathrm{mmol} / 1 \mathrm{H}_{2} \mathrm{O}_{2}$ stimulation.

\begin{tabular}{|c|c|c|c|c|c|}
\hline Group & T0 & $\mathrm{T} 2.5$ & T6 & T12 & $\mathrm{T} 24$ \\
\hline Blank control & $9.41 \pm 1.00$ & $9.65 \pm 0.81$ & $9.93 \pm 0.56$ & $11.84 \pm 1.24$ & $13.12 \pm 0.66$ \\
\hline $\mathrm{H}_{2} \mathrm{O}_{2}$ injury & $9.41 \pm 1.02^{\mathrm{a}}$ & $18.38 \pm 2.91^{\mathrm{a}, \mathrm{b}}$ & $35.85 \pm 2.66^{\mathrm{a}, \mathrm{b}}$ & $35.85 \pm 2.66^{\mathrm{a}, \mathrm{b}}$ & $57.68 \pm 2.22^{\mathrm{a}, \mathrm{b}}$ \\
\hline
\end{tabular}

${ }^{\mathrm{a}} \mathrm{P}<0.01$ vs. blank control group; ${ }^{\mathrm{b}}<0.05$ pairwise comparison between various time points in the $\mathrm{H}_{2} \mathrm{O}_{2}$ injury group. $\mathrm{H}_{2} \mathrm{O}_{2}$, hydrogen peroxide .

Table II. Oxygenation index $(\mathrm{mmHg})$ in rats with hyperoxia-induced acute lung injury in each group.

\begin{tabular}{lcccc}
\hline Group & $0 \mathrm{~h}$ & $24 \mathrm{~h}$ & $48 \mathrm{~h}$ & $72 \mathrm{~h}$ \\
\hline Control & $446.67 \pm 29.93$ & $306.19 \pm 37.23$ & $269.70 \pm 29.00$ & $203.81 \pm 43.40$ \\
PBS & $450.95 \pm 30.54$ & $310.48 \pm 29.17$ & $268.52 \pm 25.24$ & $202.87 \pm 39.86$ \\
Empty virus & $443.33 \pm 31.54$ & $307.15 \pm 31.79$ & $267.28 \pm 24.83$ & $185.24 \pm 31.22$ \\
miRNA21-5p & $444.76 \pm 30.30$ & $358.10 \pm 29.25^{\mathrm{a}}$ & $336.67 \pm 29.27^{\mathrm{a}}$ & $323.81 \pm 19.05^{\mathrm{a}}$ \\
\hline
\end{tabular}

Data are presented as the mean \pm standard deviation $(n=40) .{ }^{a} \mathrm{P}<0.05$ vs. control group at the same time point. miR, microRNA.

Table III. Respiratory index following hyperoxia-induced acute lung injury in each group.

\begin{tabular}{lcccc}
\hline Group & $0 \mathrm{~h}$ & $24 \mathrm{~h}$ & $48 \mathrm{~h}$ & $72 \mathrm{~h}$ \\
\hline Control & $0.25 \pm 0.04$ & $0.31 \pm 0.06$ & $0.38 \pm 0.06$ & $0.46 \pm 0.07$ \\
PBS & $0.26 \pm 0.05$ & $0.32 \pm 0.04$ & $0.39 \pm 0.06$ & $0.49 \pm 0.07$ \\
Empty virus & $0.25 \pm 0.05$ & $0.35 \pm 0.06$ & $0.42 \pm 0.07$ & $0.50 \pm 0.08$ \\
miRNA21-5p & $0.24 \pm 0.06$ & $0.23 \pm 0.05^{\mathrm{a}}$ & $0.28 \pm 0.07^{\mathrm{a}}$ & $0.30 \pm 0.04^{\mathrm{a}}$
\end{tabular}

Data are presented as the mean \pm standard deviation $(n=40) .{ }^{a} \mathrm{P}<0.05$ vs. control group at the same time point. miRNA, microRNA.

Table IV. Comparison of lung pathology scores in each group following hyperoxia-induced acute lung injury.

\begin{tabular}{lcccc}
\hline Group & $0 \mathrm{~h}$ & $24 \mathrm{~h}$ & $48 \mathrm{~h}$ & $72 \mathrm{~h}$ \\
\hline Control & $0.00 \pm 0.00$ & $0.90 \pm 0.74$ & $2.90 \pm 1.20$ & $4.70 \pm 1.57$ \\
PBS & $0.20 \pm 0.42$ & $0.90 \pm 0.74$ & $3.10 \pm 1.37$ & $5.00 \pm 1.49$ \\
Empty virus & $0.10 \pm 0.32$ & $0.80 \pm 0.79$ & $3.00 \pm 1.15$ & $4.30 \pm 1.16$ \\
miRNA21-5p & $0.20 \pm 0.42$ & $0.60 \pm 0.52^{\mathrm{a}}$ & $1.30 \pm 0.95^{\mathrm{a}}$ & $1.90 \pm 0.88^{\mathrm{a}}$
\end{tabular}

Data are presented as the mean \pm standard deviation $(n=40)$. ${ }^{\mathrm{P}}<0.05$, compared with the control group at the same time point. miRNA, microRNA.

hyperoxia for $0 \mathrm{~h}$, no difference in lung tissue pathology score was observed, compared with the control group $(\mathrm{P}>0.05)$. Under hyperoxia for $24 \mathrm{~h}, 48 \mathrm{~h}$ and $72 \mathrm{~h}$, no significant differences in the lung pathology scores among the control group, PBS group and the empty virus $(\mathrm{P}>0.05)$. In the miRNA-21-5p group, the lung pathology score was significantly lower $(\mathrm{P}<0.05$; Table IV)

Changes in rat lung tissue W/D weight ratio changes. With prolonged injury, the W/D ratio of the rats gradually increased. No significant difference was found in the W/D ratio between the hyperoxia $0 \mathrm{~h}$ and control groups, $(\mathrm{P}>0.05)$. Under hyperoxia for 24,48 and $72 \mathrm{~h}$, no significant differences were observed in the W/D ratio among the control group, PBS group and the empty virus group $(\mathrm{P}>0.05)$. The $\mathrm{W} / \mathrm{D}$ ratio on the miRNA-21-5p group was significantly lower $(\mathrm{P}<0.05$; Table $\mathrm{V})$

Cell transfection. Green fluorescence was observed using fluorescence microscopy to confirm that the miR-21-5p overexpressed adenoviral vector and miR-21-5p negative adenoviral vector were successfully transfected into the AEC-II, with 30 as the optimal MOI, and $48 \mathrm{~h}$ being the highest transfection efficiency time (Fig. 6). 
Table V. Rat lung wet/dry weight ratio following hyperoxia-induced acute lung injury.

\begin{tabular}{lcccc}
\hline Group & $0 \mathrm{~h}$ & $24 \mathrm{~h}$ & $48 \mathrm{~h}$ & $72 \mathrm{~h}$ \\
\hline Control & $3.84 \pm 0.61$ & $4.14 \pm 0.46$ & $4.56 \pm 0.34$ & $5.32 \pm 0.27$ \\
PBS & $3.81 \pm 0.62$ & $4.09 \pm 0.44$ & $4.49 \pm 0.54$ & $4.86 \pm 0.61$ \\
Empty virus & $3.79 \pm 0.36$ & $4.06 \pm 0.54$ & $4.42 \pm 0.27$ & $5.03 \pm 0.48$ \\
miRNA21-5p & $3.81 \pm 0.45$ & $3.77 \pm 0.38^{\mathrm{a}}$ & $3.83 \pm 0.31^{\mathrm{a}}$ & $3.89 \pm 0.31^{\mathrm{a}}$
\end{tabular}

Data are presented as the mean \pm standard deviation $(\mathrm{n}=40)$. ${ }^{\mathrm{P}} \mathrm{P}<0.05$, vs. control group at the same time point. miRNA, microRNA.

Table VI. Effect of $0.5 \mathrm{mmol} / \mathrm{H} \mathrm{H}_{2} \mathrm{O}_{2}$ on the apoptotic rates of each type II alveolar epithelial cell group.

\begin{tabular}{|c|c|c|c|c|}
\hline \multirow[b]{2}{*}{ Group } & \multicolumn{4}{|c|}{ Early apoptotic rate $(\%)$} \\
\hline & $6 \mathrm{~h}$ & $12 \mathrm{~h}$ & $24 \mathrm{~h}$ & $48 \mathrm{~h}$ \\
\hline Normal control & $2.47 \pm 0.10$ & $3.10 \pm 0.32$ & $6.05 \pm 0.38$ & $7.04 \pm 0.43$ \\
\hline $\mathrm{H}_{2} \mathrm{O}_{2}$ injury & $7.82 \pm 0.15^{\mathrm{a}}$ & $16.26 \pm 0.59^{\mathrm{a}}$ & $23.39 \pm 2.78^{\mathrm{a}}$ & $50.53 \pm 2.17^{\mathrm{a}}$ \\
\hline miR-21-5p negative transfection & $7.66 \pm 0.17^{\mathrm{a}}$ & $16.04 \pm 0.70^{\mathrm{a}}$ & $23.58 \pm 2.31^{\mathrm{a}}$ & $49.41 \pm 1.97^{\mathrm{a}}$ \\
\hline miR-21-5p overexpression & $7.68 \pm 0.20^{\mathrm{a}}$ & $10.73 \pm 2.80^{\mathrm{a}, \mathrm{b}}$ & $16.00 \pm 3.44^{\mathrm{a}, \mathrm{b}}$ & $31.30 \pm 3.55^{\mathrm{a}, \mathrm{b}}$ \\
\hline
\end{tabular}

Data are presented as the mean \pm standard deviation $(\mathrm{n}=20)$. ${ }^{\mathrm{a}} \mathrm{P}<0.05$, compared with normal control group; ${ }^{\mathrm{b}}<0.05$, compared with the $\mathrm{H}_{2} \mathrm{O}_{2}$ injury group and miR-21-5p negative transfection group. miR, microRNA; $\mathrm{H}_{2} \mathrm{O}_{2}$, hydrogen peroxide.

Table VII. Fluorescence intensity in each group.

\begin{tabular}{lllll}
\hline Group & $\mathrm{n}$ & Bcl-2 & Bax & Caspase-3 \\
\hline Normal control & 5 & $0.09 \pm 0.01$ & $0.12 \pm 0.01$ & $0.12 \pm 0.01$ \\
$\mathrm{H}_{2} \mathrm{O}_{2}$ injury & 5 & $0.06 \pm 0.01^{\mathrm{a}}$ & $0.18 \pm 0.01^{\mathrm{a}}$ & $0.23 \pm 0.01^{\mathrm{a}}$ \\
miR-21-5p negative transfection & 5 & $0.10 \pm 0.01$ & $0.13 \pm 0.01$ & $0.12 \pm 0.01$ \\
miR-21-5p overexpression & 5 & $0.26 \pm 0.01^{\mathrm{a}, \mathrm{b}}$ & $0.07 \pm 0.01^{\mathrm{a}, \mathrm{b}}$ & $0.07 \pm 0.01^{\mathrm{a}, \mathrm{b}}$
\end{tabular}

${ }^{a} \mathrm{P}<0.05$, compared with normal control group; ${ }^{\mathrm{P}} \mathrm{P}<0.05$, compared with $\mathrm{H}_{2} \mathrm{O}_{2}$ injury group. miR, microRNA; $\mathrm{H}_{2} \mathrm{O}_{2}$, hydrogen peroxide; $\mathrm{Bcl}-2$, B-cell lymphoma 2; Bax, Bcl-2-associated X protein.

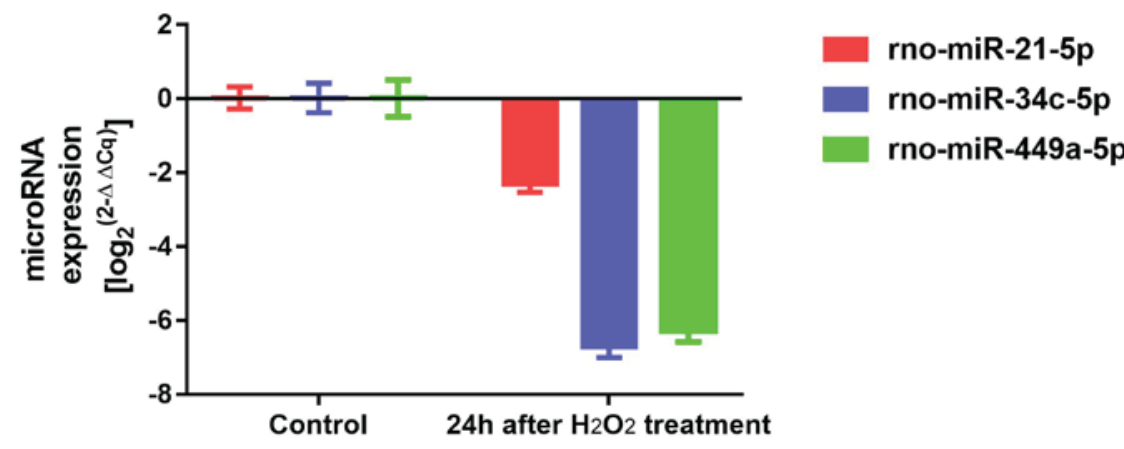

Figure 4. Verification of apoptosis-related miRNAs using reverse transcription-polymerase chain reaction analysis. miR, microRNA.

Expression of miR-21-5p. The expression of miR-21-5p in the miR-21-5p overexpression group was significantly higher, compared with that in the other three groups (all
$\mathrm{P}<0.05)$. This indicated that the miR-21-5p adenoviral overexpression vector had been constructed and transfected successfully (Fig. 7) 


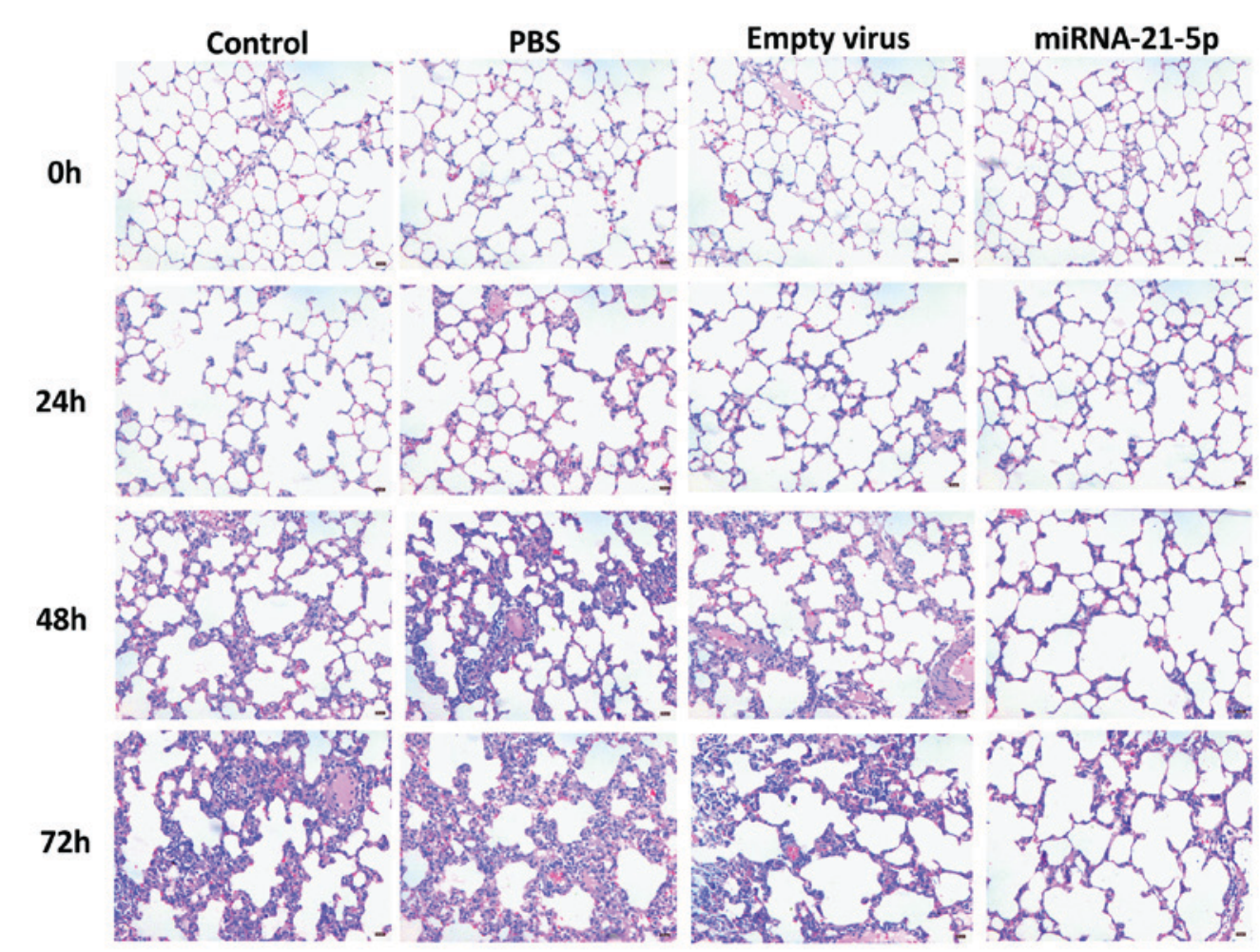

Figure 5. Pathological changes in the lung tissue at 0,24,48 and $72 \mathrm{~h}$. Pathological changes were examined using light microscopy with hematoxylin and eosin staining (magnification, x200).

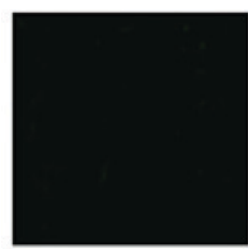

$12 \mathrm{~h}$

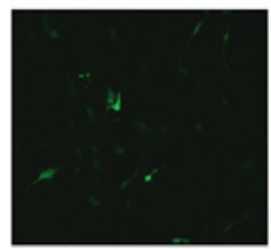

$24 \mathrm{~h}$

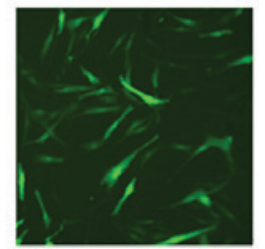

$48 \mathrm{~h}$
Figure 6. Morphology of type II alveolar epithelial cells following successful transfection using a fluorescence microscope.

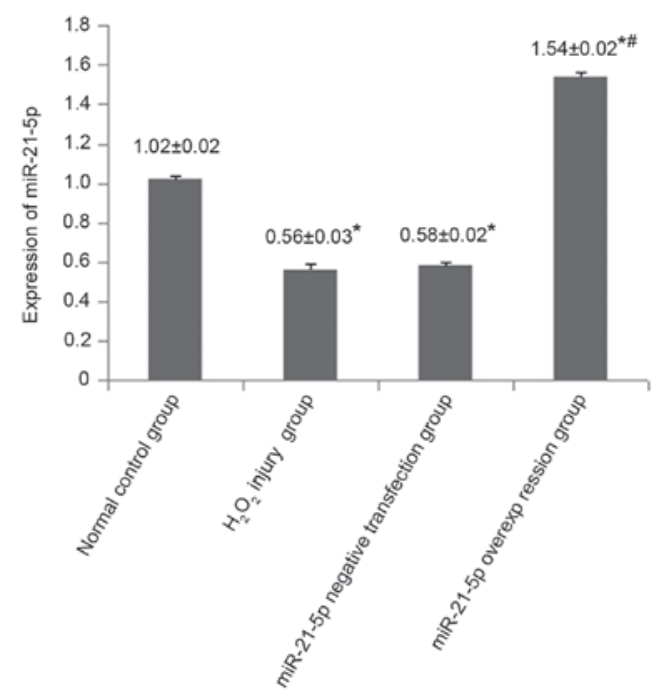

Figure 7. Fluorescence intensity of miR-21-5p at $48 \mathrm{~h}$ following adenovirus transfection. " $\mathrm{P}<0.05$ vs. normal control group; ${ }^{\#} \mathrm{P}<0.05$ vs. $\mathrm{H}_{2} \mathrm{O}_{2}$ injury group and miR-21-5p negative transfection group. miR, microRNA; $\mathrm{H}_{2} \mathrm{O}_{2}$, hydrogen peroxide.
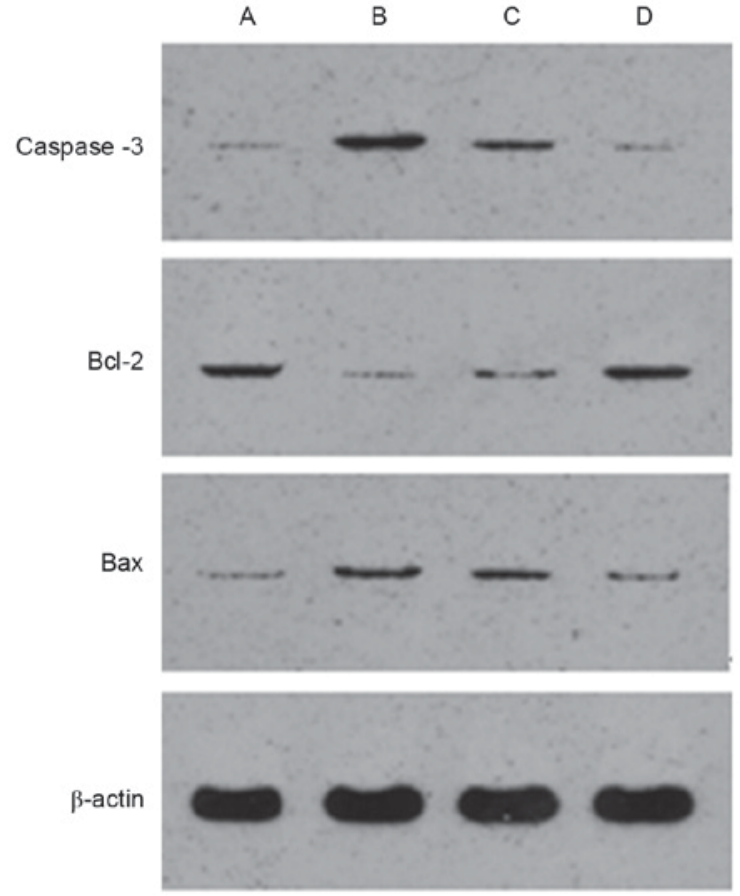

Figure 8. Expression levels of Bcl-2, Bax and caspase-3 in AEC-II of each group. (A) Normal control group; (B) $\mathrm{H}_{2} \mathrm{O}_{2}$ injury group; (C) miR-21-5p negative transfection group; (D) miR-21-5p overexpression group. miR, microRNA; $\mathrm{H}_{2} \mathrm{O}_{2}$, hydrogen peroxide; Bcl-2, B-cell lymphoma 2; Bax, Bcl-2-associated X protein.

FCM detection of early apoptotic rates. The early apoptotic rate of the $\mathrm{H}_{2} \mathrm{O}_{2}$ injury group, miR-21-5p overexpression group and miR-21-5p negative control transfection group 
gradually increased with the prolongation of injury time, compared with the normal control group $(\mathrm{P}<0.05)$. The early apoptotic rate of the miR-21-5p overexpression group was significantly lower, compared with that in the miR-21-5p negative transfection group and $\mathrm{H}_{2} \mathrm{O}_{2}$ injury group at the same point $(\mathrm{P}<0.05)$. No significant differences in the early apoptotic rates of the miR-21-5 pnegative control transfection group and $\mathrm{H}_{2} \mathrm{O}_{2}$ injury group were observed at the same time point $(\mathrm{P}>0.05$; Table VI)

Expression of Bcl-2, Bax and caspase-3. Following $48 \mathrm{~h}$ adenoviral transfection with the highest efficiency, western blot analysis was used to determine expression of $\mathrm{Bcl}-2$, Bax and caspase-3. Compared with the normal control group, the expression of Bcl-2 was significantly decreased in the $\mathrm{H}_{2} \mathrm{O}_{2}$ injury group, whereas the expression of Bax and caspase- 3 were significantly increased $(\mathrm{P}<0.05)$. In the miR-21-5p overexpression group, the expression of $\mathrm{Bcl}-2$ was significantly higher, compared with the levels in the $\mathrm{H}_{2} \mathrm{O}_{2}$ injury group and miR-21-5p negative transfection group. The protein levels of Bax and caspase- 3 were significantly lower, compared with those in the $\mathrm{H}_{2} \mathrm{O}_{2}$ injury group and miR-21-5p negative transfection group $(\mathrm{P}<0.05$; Fig. 8; Table VII).

\section{Discussion}

HALI is one of the most refractory diseases, as its specific mechanism is not fully understood. The present study aimed to identify an efficient method to prevent or treat this disease. For the experiments, a total of 38 differentially expressed miRNAs were selected, among which miR-449a-5p, miR-34b/c-5p, miR-200a/c-3p, miR-21-5p and 13 miRNAs were found to be closely associated with cell apoptosis; these miRNAs are important in the regulation of AEC-II apoptosis. This was established using high-throughput gene chip technology to screen for AEC-II apoptosis-related miRNAs. The expression of miR-21-5p was lower, compared with that of the miR-34 family, however, it had a high level of expression in the AEC-II, being 9-fold higher than that of the miR-34 family. miR-21 is recognized as an anti-apoptotic gene, functioning predominantly to reduce the $\mathrm{Bax} / \mathrm{Bcl}-2$ ratio (24-30). In addition, studies have shown that miR-21 inhibits apoptosis by targeting phosphatase and tensin homolog (PTEN) and programmed cell death 4 (Pdcd4) (31-33). Therefore, miR-21-5p may be an important anti-apoptotic gene in AEC-II, as upregulating its expression in AEC-II may inhibit apoptosis.

Bioinformatics methods are an effective means of predicting miRNA target genes; the present study examined the putative target genes of miR-449a-5p, miR-34b/c-5p and miR-21-5p. Analysis revealed that miR-21 has the most relevant association with AEC-II apoptosis. It has been reported that miR-21 can be adjusted through the $\mathrm{Bax} / \mathrm{Bcl}-2$ ratio, the expression of PTEN and Pdcd4 inhibiting apoptosis (24-33). Therefore, miR-21-5p may inhibit apoptosis by regulating the expression of Bcl-2, Pdcd4, PTEN or Fas ligand.

The results of the present study showed that, as the duration of hyperoxia was prolonged, OI, RI, W/D and lung pathology scores gradually increased, as did pathological destruction of lung tissue structure. However, when transfected with miRNA-21-5p, the OI in the miRNA-21-5p group were significantly higher, compared with that in the other three groups, and RI, W/D and lung pathology scores were significantly lower, compared with the other three groups. This indicated that miRNA-21-5p effectively reduced the degree of HALI, having a preventative effect on the rat lungs. Bcl-2 is one of the important anti-apoptosis genes and Bax is an important prop-apoptotic gene. The Bcl-2 family controls outer and inner membrane permeability, being a primary regulator of the mitochondrial apoptotic pathway, which affects a series of downstream genes involved in regulating whole cell apoptosis (34). Through examining Bcl-2, Bax and caspase- 3 changes, the present study demonstrated that miRNA-21-5p prevented AEC-II apoptosis at the cellular level. In animal and cell experiments, the present study demonstrated that miRNA-21-5p prevented AEC-II apoptosis and prevented HALI, however, its mechanism remains to be further elucidated and investigations into treatment are in progress.

Taken together, the findings of the present study assist in elucidating the molecular mechanisms and pathways of miR-21-5p as an antagonist in AEC-II apoptosis. It also provides important information for miRNA prevention and treatment of pulmonary diseases, and may provide a novel strategy for the treatment of apoptosis-related diseases, including ALI, in the future.

\section{Acknowledgements}

Not applicable.

\section{Funding}

The present study was supported by the National Natural Science Foundation of China (grant no. 81560019).

\section{Availability of data and materials}

The analyzed datasets generated during the study are available from the corresponding author on reasonable request.

\section{Authors' contributions}

SQ, HJ and GYL performed the experiments, wrote the paper and prepared figures and/or tables. MC conceived and designed the experiments, and provided the reagents/materials/analysis tools. SQ, GYL, HM, KL and TC analyzed the data. All authors reviewed drafts of the paper.

\section{Ethics approval and consent to participate}

All experimental procedures were performed according to the Guide for the Care and Use of Laboratory Animals. The protocol of the present study was approved by the Experimental Animal Care and Use Committee of Zunyi Medical University (Zunyi, China).

\section{Consent for publication}

Not applicable. 


\section{Competing interests}

The authors declare that they have no competing interests.

\section{References}

1. Bhandari V, Choo-Wing R, Harijith A, Sun H, Syed MA, Homer RJ and Elias JA: Increased hyperoxia-induced lung injury in nitric oxide synthase 2 null mice is mediated via angiopoietin 2. Am J Respir Cell Mol Biol 46: 668-676, 2012

2. Lee HS and Kim CK: Effect of recombinant IL-10 on cultured fetal rat alveolar type II cells exposed to 65\%-hyperoxia. Respir Res 12: 68, 2011

3. Ma X, Xu D, Ai Y, Ming G and Zhao S: Fas inhibition attenuates lipopolysaccharide-induced apoptosis and cytokine release of rat type II alveolar epithelial cells. Mol Biol Rep 37: 3051-3056, 2010.

4. Liu H, Ma L, Wu J, Wang K and Chen X: Apoptosis of alveolar wall cells in chronic obstructive pulmonary disease patients with pulmonary emphysema is involved in emphysematous changes. J Huazhong Univ Sci Technolog Med Sci 29: 466-469, 2009.

5. Kamp DW, Liu G, Cheresh P,Kim SJ, Mueller A, Lam AP, Trejo H, Williams D, Tulasiram S, Baker M, et al: Asbestos-induced alveolar epithelial cell apoptosis. the role of endoplasmic reticulum stress response. Am J Respir Cell Mol Biol 49: 892-901, 2013.

6. Lee HS and Kim CK: Cathepsin B is activated as an executive protease in fetal rat alveolar type II cells exposed to hyperoxia. Exp Mol Med 43: 223-229, 2011.

7. Hengartner MO: The biochemistry of apoptosis. Nature 407: 770-776, 2000

8. Liang X, Wei SQ, Lee SJ, Fung JK, Zhang M, Tanaka A, Choi AM and Jin Y: p62 sequestosome 1/light chain $3 \mathrm{~b}$ complex confers cytoprotection on lung epithelial cells after hyperoxia. Am J Respir Cell Mol Biol 48: 489-496, 2013.

9. Li L, Wu W, Huang W, Hu G, Yuan W and Li W: NF- $\kappa B$ RNAi decreases the Bax/Bcl-2 ratio and inhibits TNF- $\alpha$-induced apoptosis in human alveolar epithelial cells. Inflamm Res 62: 387-397, 2013.

10. Husari AW, Khayat A, Awdeh H, Hatoum H, Nasser M, Mroueh SM, Zaatari G, El-Sabban M and Dbaibo GS: Activated protein $\mathrm{C}$ attenuates acute lung injury and apoptosis in a hyperoxic animal model. Shock 33: 467-472, 2010.

11. Zhang M, Lin L, Lee SJ, Mo L, Cao J, Ifedigbo E and Jin Y: Deletion of caveolin-1 protects hyperoxia-induced apoptosis via survivin-mediated pathways. Am J Physiol Lung Cell Mol Physiol 297: 945-953, 2009.

12. Perl M, Chung CS, Perl U, Lomas-Neira J, de Paepe M, Cioffi WG and Ayala A: Fas-induced pulmonary apoptosis and inflammation during indirect acute lung injury. Am J Respir Crit Care Med 176: 591-601, 2007.

13. Geiser T, Ishigaki M, Van LC, Matthay MA and Broaddus VC: $\mathrm{H}(2) \mathrm{O}(2)$ inhibits alveolar epithelial wound repair in vitro by induction of apoptosis. Am J Physiol Lung Cell Mol Physiol 287: 448-453, 2004

14. Neill S, Desikan R and Hancock J: Hydrogen peroxide signalling. Curr Opin Plant Biol 5: 388-395, 2002.

15. Bailey SG, Sanchez-Elsner T, Stephanou A, Cragg MS and Townsend PA: Regulating the genome surveillance system: miRNAs and the p53 super family. Apoptosis 15: 541-552, 2010.

16. Garofalo M, Condorelli GL, Croce CM and Condorelli G: MicroRNAs as regulators of death receptors signaling. Cell Death Differ 17: 200-208, 2010.

17. Wang Y and Lee CG: MicroRNA and cancer-focus on apoptosis. J Cell Mol Med 13: 12-23, 2009.

18. Xu P, Guo M and Hay BA: MicroRNAs and the regulation of cell death. Trends Genet 20: 617-624, 2004.
19. Shi M, Jin GP, Liu QH and Liu CT: Establishment and evaluation of rat model of hyperoxia induced acute lung injury. Chinese J Resp Crit Care Med 2011 (In Chinese).

20. Saeed AI, Bhagabati NK, Braisted JC, Liang W, Sharov V, Howe EA, Li J, Thiagarajan M, White JA and Quackenbush J: TM4 microarray software suite. Methods Enzymol 411: 134-193, 2006.

21. Livak KJ and Schmittgen TD: Analysis of relative gene expression data using real-time quantitative PCR and the 2(-Delta Delta C(T)) method. Methods 25: 402-408, 2001

22. Mayer J, Laine VJ, Rau B, Hotz HG, Foitzik T, Nevalainen TJ and Beger HG: Systemic lymphocyte activation modulates the severity of diet-induced acute pancreatitis in mice. Pancreas 19: 62-68, 1999.

23. Osman MO, Kristensen JU, Jacobsen NO, Lausten SB, Deleuran B, Deleuran M, Gesser B, Matsushima K, Larsen CG and Jensen SL: A monoclonal anti-interleukin 8 antibody (WS-4) inhibits cytokineresponse and acute lung injury in experimental severe acute necrotisingpancreatitis in rabbits. Gut 43: 232-239, 1998.

24. Cimmino A, Calin GA, Fabbri M, Iorio MV, Ferracin M, Shimizu M, Wojcik SE, Aqeilan RI, Zupo S, Dono M, et al: miR-15 and miR-16 induce apoptosis by targeting BCL2. Proc Natl Acad Sci USA 102: 13944-13949, 2005.

25. Calin GA, Dumitru CD, Shimizu M, Bichi R, Zupo S, Noch E, Aldler H, Rattan S, Keating M, Rai K, et al: Frequent deletions and down-regulation of micro-RNA genes miR15 and miR16 at 13 q14 in chronic lymphocytic leukemia. Proc Natl Acad Sci USA 99: 15524-15529, 2002

26. Galluzzi L, Morselli E, Vitale I, Kepp O, Senovilla L, Criollo A, Servant N, Paccard C, Hupé P, Robert T, et al: miR-181a and miR-630 regulate cisplatin-induced cancer cell death. Cancer Res 70: 1793-1803, 2010.

27. Si ML, Zhu S, Wu H, Lu Z, Wu F and Mo YY: MiR-21-mediated tumor growth. Oncogene 26: 2799-2803, 2007.

28. Liu P, Liang H, Xia Q, Li P, Kong H, Lei P, Wang S and Tu Z: Resveratrol induces apoptosis of pancreatic cancers cells by inhibiting miR-21 regulation of BCL-2 expression. Clin Transl Oncol 15: 741-746, 2013

29. Hu HY, Li KP, Wang XJ, Liu Y, Lu ZG, Dong RH, Guo HB and Zhang MX: Set9, NF- $\kappa$ B, and microRNA-21 mediate berberine-induced apoptosis of human multiple myeloma cells Acta Pharmacol Sin 34: 157-166, 2013.

30. Shi L, Chen J, Yang J, Pan T, Zhang S and Wang Z: MiR-21 protected human glioblastoma U87MG cells from chemotherapeutic drug temozolomide induced apoptosis by decreasing Bax/Bcl-2 ratio and caspase-3 activity. Brain Res 1352: 255-264, 2010.

31. Yang SM, Huang C, Li XF, Yu MZ, He Y and Li J: miR-21 confers cisplatin resistance in gastric cancer cells by regulating PTEN. Toxicology 306: 162-168, 2013.

32. Xiong B, Cheng Y, Ma L and Zhang C: MiR-21 regulates biological behavior through the PTEN/PI-3 K/Akt signaling pathway in human colorectal cancer cells. Int J Oncol 42: 219-228, 2013.

33. Itani S, Kunisada T, Morimoto Y, Yoshida A, Sasaki T, Ito S, Ouchida M, Sugihara S, Shimizu K and Ozaki T: MicroRNA-21 correlates with tumorigenesis in malignant peripheral nerve sheath tumor (MPNST) via programmed cell death protein 4 (PDCD4). J Cancer Res Clin Oncol 138: 1501-1509, 2012.

34. Tsukahara S, Yamamoto S, Tin-Tin-Win-Shwe, Ahmed S, Kunugita N, Arashidani $\mathrm{K}$ and Fujimaki $\mathrm{H}$ : Inhalation of low-level formaldehyde increases the $\mathrm{Bcl}-2 / \mathrm{Bax}$ expression ratio in the hippocampus of immunologically sensitized mice. Neuroimmunomodulation 13: 63-68, 2006.

This work is licensed under a Creative Commons Attribution-NonCommercial-NoDerivatives 4.0 International (CC BY-NC-ND 4.0) License. 